\title{
CAMINHOS QUE LEVAM À CORTE: CARREIRAS E PADRÕES DE RECRUTAMENTO DOS MINISTROS DOS ÓRGÃOS DE CÚPULA DO PODER JUDICIÁRIO BRASILEIRO (1829-2006) ${ }^{1}$
}

\author{
André Marenco dos Santos
}

\author{
Luciano Da Ros
}

\begin{abstract}
RESUMO
O artigo analisa mudanças e continuidades nos padrões de recrutamento dos ministros dos órgãos de cúpula do poder Judiciário brasileiro entre 1829 e 2006. Para isso, são analisados dados relativos a 1) origem social e 2) carreiras jurídicas, políticas e coercitivas dos membros do Supremo Tribunal de Justiça (1829-1890) e do Supremo Tribunal Federal (1891-2006). Isolamos os atributos sociais dos indivíduos recrutados para essas cortes, identificando características próprias a cada geração de ministros, salientando a importância das instituições universitárias específicas na projeção de carreiras jurídicas, os estados de origem e a ocorrência de fenômenos de mobilidade geográfica em diferentes períodos. Observamos ainda o grau de diferenciação da arena jurídica em relação àquelas de natureza propriamente política, ponto considerado fundamental para a institucionalização do órgão. Os resultados observados oferecem pistas para a compreensão de mudanças longitudinais existentes nos padrões de carreira e recrutamento para as cortes supremas brasileiras e os requisitos sociais, institucionais e políticos que acompanham trajetórias nessa parcela do campo jurídico. Fundamentalmente, observa-se lento incremento de indivíduos provenientes do universo exclusivamente jurídico, prevalecendo durante a maior parte do tempo indivíduos que percorreram carreiras tanto no campo jurídico como em outras arenas, sejam elas políticas ou ligadas ao aparato coercitivo do Estado. O decréscimo da circulação geográfica ao longo da carreira dos futuros ministros, bem como a diversificação de suas instituições superiores de diplomação, ambos em especial após a primeira Era Vargas, sugerem, ainda que um tanto paradoxalmente, incremento da autonomia do órgão.
\end{abstract}

PALAVRAS-CHAVE: carreiras jurídicas; padrões de recrutamento; Supremo Tribunal Federal; Supremo Tribunal de Justiça.

\section{INTRODUÇÃO}

Pelo menos desde meados da década de 1990, uma crescente atenção dos cientistas sociais - e dos cientistas políticos, em especial - tem sido dada ao estudo de instituições judiciais no Brasil. A ênfase, em geral, tem recaído sobre o Supremo Tribunal Federal - órgão de cúpula do poder Judiciário e instância última na interpretação jurisdicional da Constituição - e buscado identifi-

\footnotetext{
1 O presente artigo é uma versão ligeiramente modificada de trabalho apresentado no seminário temático "Elites e Instituições Políticas”, parte integrante do $31^{\circ}$ Encontro Anual da Associação Nacional de Pós-Graduação e Pesquisa em Ciências Sociais (Anpocs), realizado em Caxambu, Minas Gerais, entre 22 e 26 de outubro de 2007. Agradecemos aos presentes na sessão de apresentação pelas sugestões e críticas que, na medida do possível, foram incorporadas a esta versão. Os equívocos remanescentes, como de praxe, são de inteira responsabilidade dos autores.
}

car o papel exercido por essa instituição no processo político nacional. Contudo, se considerável atenção tem sido, por um lado, dedicada à relação do tribunal com as demais arenas decisórias, por outro, poucos são os esforços de sistematização a respeito dos perfis referentes aos integrantes daquela corte.

O presente estudo busca iniciar o preenchimento desta lacuna, objetivando compreender os padrões de carreira e de recrutamento dos ministros que tomaram assento naqueles que foram os órgãos de cúpula do poder Judiciário ao longo da história brasileira, quais sejam: o Supremo Tribunal de Justiça (STJi) ${ }^{2}$, existente durante a maior parte do período imperial, e o Supremo Tribunal

\footnotetext{
2 Adotamos a abreviação STJi para designar o Supremo Tribunal de Justiça do Império com o propósito de diferenciá-la daquela comumente empregada na referência
} 
Federal (STF), congênere instaurado a partir da primeira Constituição republicana, em 1891.

A pesquisa aqui apresentada justifica-se basicamente por quatro razões. A primeira deriva em parte da própria literatura sobre a chamada judicialização da política, que não raramente busca explicar o que seria um comportamento autorestritivo do STF com base nos métodos de recrutamento e de investidura dos quadros do tribunal (CARVALHO NETO, 2000, p. 58-61; CASTRO \& RIBEIRO, 2006, p. 20). Nesse sentido, esta pesquisa busca identificar justamente os efeitos destes métodos, comparando longitudinalmente a composição da instituição com o fim de observar as tendências de alterações temporais e espaciais no recrutamento dos referidos ministros.

Em segundo lugar, estudos recentes buscam demonstrar que as diferentes composições dos tribunais, decorrentes de perfis distintos de recrutamento e de carreira dos seus integrantes, alterariam o modo pelo qual eles decidem, gerando efeitos sobre o modo de atuação da instituição como um todo (MARANHÃO, 2003; OLIVEIRA, 2006) $)^{3}$. Compreender as diferentes composições pode auxiliar no entendimento de tendências gerais de atuação do tribunal ao longo de diferentes períodos históricos, ainda que uma aproximação desta monta seja, obviamente, um tanto imprecisa.

Ainda como justificativa, seria importante lembrar que pelo menos dois estudos influentes buscaram traçar os perfis dos magistrados brasilei-

ao Superior Tribunal de Justiça (STJ), órgão criado a partir da Constituição de 1988.

3 Observe-se, contudo, que esta leitura não é isenta de controvérsia. Na realidade, as principais hipóteses presentes na literatura especializada rejeitam a existência de nexo causal entre os padrões de carreira e o comportamento efetivo destes mesmos magistrados. Longe de constituir-se uma unanimidade, as visões preponderantes sobre o comportamento dos tribunais geralmente levam em consideração ou as preferências políticas individuais dos magistrados (o chamado “modelo atitudinal”), não sendo necessariamente relevantes suas respectivas carreiras, ou a atuação estratégica do tribunal frente aos demais atores políticos (conhecido por "modelo de separação dos poderes", variante do "modelo estratégico"). Em ambos os casos, entretanto, o comportamento judicial não é explicado em função dos padrões de recrutamento, sugerindo, inclusive, a fragilidade dessa hipótese. Como exemplos dessas abordagens, ver, por um lado, os trabalhos de Jeffrey Segal e Harold Spaeth $(1993 ; 2002)$ e, por outro lado, os trabalhos de Georg Vanberg (2001) e de Gretchen Helmke (2002). ros, mas pouca ou nenhuma atenção foi dada naquelas obras aos perfis dos magistrados dos tribunais superiores (WERNECK VIANNA et alii, 1997; SADEK, 2006) ${ }^{4}$. Dessa maneira, a presente pesquisa seria complementar àquelas.

Por fim, o ponto mais interessante. Alguns estudos indicam que a institucionalização dos órgãos de cúpula do poder Judiciário estaria ligada ao tipo de integrantes recrutados para estes. A profissionalização dos membros e a diferenciação do perfil destes em relação aos demais órgãos do Estado são consideradas, por determinados autores, partes importantes no processo de institucionalização dos órgãos do poder Judiciário (GUARNIERI \& PEDERZOLI, 1996; BONELLI, 2001; 2002; MCGUIRE, 2004; BONELLI, OLIVEIRA \& MARTINS, 2006). Conclusões semelhantes podem inclusive ser encontradas no que se refere à institucionalização de outros órgãos políticos, como o poder Legislativo (POLSBY, 1968). Desse modo, a presente pesquisa pode contribuir diretamente para a observação de um dos elementos que contribuem para a maior ou a menor institucionalização dos órgãos de cúpula do poder Judiciário no Brasil, conforme será detalhado adiante.

Ainda em tempo, uma ressalva merece ser realizada. A presente pesquisa não pretende analisar as regras de recrutamento dos integrantes dos referidos tribunais e tampouco enfatiza o processo de escolha e indicação dos ministros, ao contrário do que se prioriza, por exemplo, na análise política referente ao estudo da Suprema Corte nos EUA $^{5}$. Busca-se, antes, traçar o perfil dos membros recrutados para estas instituições, fazendose menção às diferentes regras de escolha quando estas forem necessárias à compreensão mais adequada do estudo que ora se introduz.

4 Como exceção à tendência apresentada por estas obras, cujo foco recai exclusivamente sobre os magistrados de primeira e segunda instâncias, pode-se indicar O perfil do magistrado brasileiro, de Luiz Werneck Vianna et alii (1996), em que, além dos anteriores, são também mapeados os perfis de ministros integrantes de tribunais superiores.

${ }^{5}$ Há inúmeros estudos a respeito de estratégias e impasses decorrentes do processo de indicação de um novo justice para a Suprema Corte dos EUA. Entre esses, apenas para exemplificar, pode-se citar o extenso trabalho de Lee Epstein e Jeffrey Segal (2005). Ressalte-se, novamente, que o objetivo do presente artigo não é realizar um estudo à semelhança destes. 


\section{APRESENTAÇÃO DAS CATEGORIAS DE ANÁLISE}

A ênfase pretendida na análise dos ministros do STJi e do STF recai sobre a importância da profissionalização e da diferenciação no processo de institucionalização do tribunal. Trata-se, em síntese, de observar a ocorrência ou não de um recrutamento endógeno à magistratura e às demais carreiras estritamente jurídicas. Uma vez verificado este padrão, estar-se-ia a recrutar profissionais próprios da área do Direito, estabelecendo padrão mais autônomo e contribuindo para a diferenciação do poder Judiciário em relação aos demais órgãos do Estado. Neste caso, a referida diferenciação no padrão de recrutamento ocorre basicamente em dois níveis. O primeiro diz respeito àquelas carreiras ditas "políticas", ligadas especialmente à ocupação de cargos junto aos poderes Legislativo e Executivo, tanto de natureza eletiva como proveniente de nomeação. Nesta situação, maior distinção entre uma e outra asseguraria maior independência das funções jurisdicionais em relação ao ambiente político, permitindo a existência de função autônoma do Direito. Em segundo lugar, deve-se observar a mesma diferenciação em relação àquelas carreiras ligadas diretamente ao exercício da coerção por parte do Estado, em que se destacam os cargos ocupados junto às forças policiais e militares, ligadas à administração da manutenção da ordem, tanto interna quanto externa. Nesta situação, a diferenciação leva a supor que as funções jurisdicionais estão separando-se daquelas de uso repressivo da violência por parte da autoridade política.

De modo a ilustrar a importância dada a este critério de diferenciação, importa frisar que a criação de tribunais constitucionais na Europa, ao longo da segunda metade do século XX apresentou claramente essa preocupação, impondo critérios bastante seletivos à escolha dos futuros membros daqueles tribunais, inclusive com ênfase sobre o recrutamento endógeno ao poder Judiciário e às demais carreiras jurídicas, em sentido oposto ao que se verifica na regra brasileira, inspirada em matriz estadunidense, na qual vige larga dose de discricionariedade do Presidente da República ${ }^{6}$.

6 O estudo de Carlo Guarnieri, Pedro Magalhães e Yorgos Kaminis (2006) demonstra claramente a proposição a respeito da preocupação dos países do sul da Europa com a regra de recrutamento.
Cumpre observar, entretanto, que a regra decisória, considerada isoladamente, não se constituiu exatamente em um empecilho à institucionalização e ao fortalecimento da Suprema Corte no sistema político dos EUA, para ficar com apenas um exemplo imediato ${ }^{7}$.

Por fim, deve-se ter em mente também como as alterações do contexto político geraram efeitos sobre a composição do tribunal ao longo do tempo. Aumento e redução do número de ministros, além de aposentadorias forçadas, entre outros, foram alguns dos instrumentos empregados pelos diversos regimes políticos no intuito de enquadrar a atuação do tribunal aos moldes desejados pela elite política do momento.

Para delinear os pretendidos perfis, foram pesquisadas as biografias dos ministros do STJi e do STF, disponíveis no portal eletrônico do órgão (cf. BRASIL. SUPREMO TRIBUNAL FEDERAL, 2007e). A organização do banco de dados contemplou informações referentes ao ano e estado de nascimento, profissão paterna (quando disponível), instituição, estado e ano da diplomação superior, cargos públicos, estados percorridos na carreira, filiação partidária, tempo de permanência no tribunal, padrões de carreira e circulação entre instituições públicas. Este conjunto de variáveis oferece oportunidade para um exame sobre as mudanças nos padrões de carreira jurídica dos futuros integrantes da Corte Suprema brasileira, durante um intervalo amplo de praticamente 180 anos. O foco da análise foi dirigido para dois processos: em primeiro lugar, a dimensão da mobilidade geográfica empreendida pelos ministros, revelada pela discrepância entre estado de nascimento, instituição onde os estudos superiores foram realizados, estado do primeiro cargo público ocupado e unidades federativas de cada um dos postos preenchidos durante a trajetória profissional até o momento de sua nomeação para integrar a mais alta Corte de Justiça do país. Trata-se de verificar a medida em que a circulação territorial constituiu estratégia necessária para a ascensão profissional e, em caso positivo, suas conseqüências para a fixação de padrões institucionais de recrutamento. Paralelamente, pretende-se

\footnotetext{
7 Vale ressaltar, contudo, que a regra de indicação brasileira, idêntica à estadunidense, é mal vista pelos próprios integrantes do poder Judiciário, especialmente pelos juízes e desembargadores (SADEK, 2006, p. 53).
} 
mensurar a circulação prévia entre diferentes instituições do Estado brasileiro (poder Legislativo, poder Executivo, burocracias), igualmente como exigência para a mobilidade profissional e o acesso a posições superiores da magistratura. A freqüência de carreiras percorridas exclusivamente nas instituições do poder Judiciário e a (in)experiência política dos futuros ministros podem indicar a presença de um processo de institucionalização da Corte.

III. O PERFIL DOS MINISTROS DO SUPREMO TRIBUNAL DE JUSTIÇA DO IMPÉRIO (1829-1891)

No período antecedente à independência do Brasil, a instância máxima do poder Judiciário era a Casa de Suplicação, instituída pelo Príncipe Regente Dom Pedro, em 10 de maio de 1808, ano da vinda da família real portuguesa ao Brasil. Este tribunal, considerado por muitos o marco da fundação do poder Judiciário no Brasil, possuía 23 membros e somente foi extinto em 1831, quando do estabelecimento do Tribunal da Relação do Rio de Janeiro. O STJi, apesar de previsto na Constituição de 1824, foi instalado apenas em 9 de janeiro de 1829 , conforme dispôs lei de 18 de setembro de 1828. Sua composição era de 17 ministros, que deveriam ser juízes letrados retirados das Relações com base em critério de antiguidade, conforme ditava o artigo 163 da Constituição do Império. Seguindo a política de concessão de títulos nobiliárquicos a praticamente todas as figuras públicas relevantes da época, os ministros, para serem nomeados, deveriam receber o título do Conselho. Observe-se que a regra constitucional previa que, para a criação da referida corte, poder-se-iam aproveitar julgadores dos tribunais que fossem eventualmente abolidos.

Cumpre salientar de antemão que entre as atribuições do órgão não se encontrava a faculdade de analisar a constitucionalidade de leis, ao contrário do que veio a ser atribuído ao Supremo Tribunal Federal, quando da republicanização do país. Tratava-se de função atribuída ao Conselho de Estado durante o período imperial. Também ao contrário do STF, o STJi não apresentou variações no número de integrantes. Este manteve-se estável, em 17 integrantes, desde a instalação da Corte, em 1829. Outra diferença entre os tribunais também merece ser destacada. Conforme já foi observado anteriormente, a regra de escolha dos integrantes do STJi era muito mais restritiva do que aquela do tribunal que o sucedeu. Neste caso, a regra obrigava as demais autoridades públicas e, especialmente, o Imperador - a quem cabia a nomeação - a que o aludido recrutamento fosse realizado no interior da função judicial, excluindo inclusive outras carreiras ligadas ao exercício do Direito, como a advocacia. A regra ainda determinava que esta escolha fosse realizada por critério de antiguidade, o que tornava ainda mais restritas as opções. Em contraponto a esses critérios restritivos, por outro lado, encontrava-se a necessidade do título do Conselho para que fosse o escolhido efetivamente nomeado para o cargo de Ministro do STJi. Pode-se supor, portanto, que esta exigência apontava para uma possibilidade de maior seletividade na escolha, isto porque permitia ao Imperador conceder o título somente àqueles que realmente desejasse apontar para o cargo, não o concedendo a outros que não pretendesse indicar ao tribunal.

Ainda sobre a regra de investidura, interessa observar que o critério de escolha recaía sobre aqueles juízes ditos letrados, isto é, portadores de diploma em Direito e conhecedores - ao menos em tese - deste campo. Não se trata de uma observação óbvia. O fato dos ministros deverem ser letrados restringia sobremaneira o leque de opções e, curiosamente, em sentido favorável ao governo central. Isto porque os juízes letrados eram aqueles ocupantes dos cargos de Juiz de Fora e, posteriormente, de Juiz de Direito. Tratava-se de cargo ocupado por aqueles assim designados pelo Imperador e, na maior parte do tempo, sob controle do Ministério da Justiça. Ao contrário, os juízes de paz eram eleitos pelos grupos locais, fazendo-se frequentemente presentes indivíduos não letrados, isto é, sem diploma jurídico. $\mathrm{O}$ fato de os ministros deverem ser recrutados dentre aqueles letrados, portanto, encontrava-se em consonância com a estratégia de construção de uma elite nacional, para além dos particularismos locais. Os dados encontrados corroboram essa hipótese. Entre os 124 ministros nomeados no período, praticamente três quartos ingressaram no Judiciário por meio de nomeação para o cargo de Juiz de Fora (46.8\%) ou Juiz de Direito (26,6\%). Nos demais casos, observa-se que todos eram de nomeação direta do Imperador (Ouvidor, Juiz do Crime, Juiz Municipal e desembargadores).

Antes, entretanto, de se passar à análise propriamente dita dos ministros designados para o 
STJi, uma observação de caráter metodológico deve ser realizada. O período histórico coberto pela existência do STJi, de 1829 a 1891, engloba 4 diferentes configurações institucionais da história política brasileira, quais sejam: o final do I Reinado (1829-1831), a Regência (1831-1840), o II Reinado (1840-1889) e ainda um pequeno intervalo durante a I República (1889-1891), quando, então, o tribunal foi substituído pelo STF. Para melhor apreender estes dados, preferiu-se agrupálos em dois períodos distintos. O primeiro referese à institucionalização do Estado nacional brasileiro e agrupa os dados dos 24 ministros nomeados durante o I Reinado e a Regência, entre 1829 e 1840. O segundo período reúne exatos $100 \mathrm{mi}-$ nistros, nomeados entre 1840 e 1891, agrupando os dados do II Reinado e dos primeiros dois anos da República. Preferiu-se proceder desta maneira a fim de não criar dois grupos de análise - Regência e I República - com número muito restrito de $\operatorname{casos}^{8}$. Isto posto, pode-se passar à análise propriamente dita dos resultados.

Primeiramente, como conseqüência dos critérios apontados acima, deve-se reconhecer que todos os 124 ministros, dos dois períodos analisados, já haviam sido nomeados desembargadores quando de suas indicações ao STJi, muitos dos quais inclusive encontravam-se exercendo o car- go quando da nomeação. Entretanto, cumpre observar que a posse do cargo de Desembargador não constituía óbice à ocupação de outros cargos - de natureza jurídica ou não - durante o mesmo período. Tanto cargos de natureza política, junto aos poderes Executivo e Legislativo, quanto cargos propriamente coercitivos, ligados à administração direta da atividade repressiva do Estado, junto às atividades policiais e militares, destacamse entre aqueles exercidos pelos nomeados a ministros do STJi. Observe-se, portanto, que apesar da regra do artigo 163 da Constituição do Império restringir a opção dos indicados àqueles que de fato ocupam cargo junto às Relações, isso, contudo, não circunscreveu as carreiras dos futuros ministros a indivíduos ocupantes de profissões exclusivamente jurídicas.

De maneira semelhante, apesar de muitos terem desenvolvido carreira junto ao poder Judiciário, isto também não impediu que, em meio ao exercício dessas funções, desempenhassem outras, sejam elas de natureza jurídica ou não, em sentido idêntico ao previamente exposto. Há, enfim, presença marcante de acúmulo de cargos entre aqueles que tornaram-se ministros do STJi, bem como ampla circulação destes entre diversas arenas estatais. O Quadro 1, abaixo, sintetiza o que se busca expor.

QUADRO 1 - EXPERIÊNCIA POLÍTICA, COERCITIVAEADMINISTRATIVA DOS MINISTROS DO STJI

\begin{tabular}{|c|c|c|c|}
\hline \multirow[t]{2}{*}{ ÂMBITO } & \multicolumn{2}{|c|}{ PERÍODO } & \multirow[t]{2}{*}{ TOTAL } \\
\hline & $\begin{array}{l}\text { I REINADOE } \\
\text { REGÊNCIA }\end{array}$ & $\begin{array}{l}\text { II REINADO E } \\
\text { I REPÚBLICA }\end{array}$ & \\
\hline Poder Executivo & $37,5 \%$ (9 de 24$)$ & $45 \%$ (45 de 100 ) & $43,5 \%$ (54 de 124) \\
\hline Poder Legislativo & $45,8 \%$ (11 de 24$)$ & $49 \%$ (49 de 100 ) & $48,4 \%$ (60 de 124$)$ \\
\hline Funçỗes militares & $25 \%$ (6 de 24$)$ & $21 \%$ (21 de 100$)$ & $21,8 \%$ (27 de 124) \\
\hline Funçỗes policiais & $16,7 \%$ (4 de 24$)$ & $38 \%$ (38 de 100$)$ & $33,9 \%$ (42 de 124$)$ \\
\hline $\begin{array}{l}\text { Cargo administrativo (excluído o } \\
\text { cargo de Provedor) }\end{array}$ & $29,2 \%$ ( 7 de 24$)$ & $8 \%$ (8 de 100$)$ & $12,1 \%$ (15 de 124$)$ \\
\hline $\begin{array}{l}\text { Cargo administrativo (incluído o } \\
\text { cargo de Provedor) }\end{array}$ & $62,5 \%$ (15 de 24$)$ & $35 \%$ (35 de 100$)$ & $40,3 \%$ (50 de 124) \\
\hline $\begin{array}{l}\text { Nomeaçỗes para serviços ao } \\
\text { governo }\end{array}$ & $20,8 \%$ (5 de 24$)$ & $6 \%$ (6 de 100$)$ & $8,9 \%$ (11 de 124$)$ \\
\hline
\end{tabular}

FONTE: os autores, a partir de Brasil. Supremo Tribunal Federal (2007), até 20.set.2007.

NOTA: nos "Cargos administrativos", excluiu-se o de Provedor da Fazenda dos Defuntos e Ausentes, Resíduos e Capelas, comum nos anos iniciais de atividade judiciária em comarcas distantes dos principais centros urbanos do período.

8 Durante a Regência, apenas sete ministros foram nomeados. Já durante os dois primeiros anos da República, apenas dois foram indicados para preencher o cargo. Embora o período referente ao I Reinado seja bastante restrito - dois anos apenas - deve-se lembrar que durante este foi instalado o próprio tribunal, ao qual foram nomeados os $17 \mathrm{mi}-$ nistros relativos à primeira composição da Corte. 
Como se observa, há elevada participação em atividades diretamente políticas, junto aos poderes Executivo e Legislativo. De modo agregado, percebe-se que $64,5 \%$ dos ministros do STJi tiveram alguma vivência neste tipo de atividade $66,7 \%$ das nomeações realizadas entre 1829 e 1840, e 64\% daquelas realizadas entre 1840 e 1891 apresentam esse perfil. Entretanto, em que pese o elevado índice de ministros com experiência diretamente política, muitos dos quais de natureza parlamentar, deve-se mencionar que os dados sobre filiação partidária são irrisórios - o perfil de apenas dois membros do STJi apresenta essa informação, ambos do Partido Conservador. Muitos dos futuros integrantes do tribunal ocuparam cargos como os de Vereador e Senador, mas especialmente o de Deputado junto à Assembléia Geral. Em sentido semelhante, percebe-se que muitos ocuparam - em caráter provisório ou permanente - o cargo de Presidente de província, para não mencionar aqueles que foram ministros de Estado durante certo período.

Deve-se perceber que a baixa diferenciação ocorre também em relação às atividades coercitiva do Estado. Há elevada participação nestas atividades por parte daqueles que vieram a integrar o órgão de cúpula do poder Judiciário do período. No total, $48,4 \%$ dos ministros serviram diretamente na administração das funções policiais e militares - 37,5\% e 51\% dos integrantes do STJi apresentaram esse perfil durante os dois períodos analisados, respectivamente. Cargos como os de Chefe de Polícia, Delegado de Polícia e IntendenteGeral de Polícia, assim como os de Auditor de Guerra e Ministro do Conselho Supremo Militar não raramente foram exercidos antes da nomeação ao STJi

Em sentido semelhante, os dados também permitem observar a presença marcante do exercício de cargos administrativos, em especial, quando se agrega aquele de Provedor da Fazenda dos Defuntos e Ausentes, Resíduos e Capelas. Muitos magistrados, em início de carreira, ao assumirem seus primeiros postos no poder Judiciário, assumiam conjuntamente essa função, aproximandose de uma espécie de administrador local em povoamentos mais distantes dos grandes centros urbanos. Quanto aos outros cargos, geralmente ligavam-se ao exercício de alguma forma de atividade de fiscalização, especialmente no que se refere à arrecadação de tributos, como os cargos de Intendente do Ouro e de Intendente dos Diamantes da Corte.

Como conseqüência desse quadro, percebese que há reduzida presença daqueles ministros que apresentaram carreiras exclusivamente jurídicas. Mesmo nesse caso, percebe-se que um número não insignificante deles exerceu, em algum momento de sua carreira, atividades ligadas à defesa jurídica do próprio Estado. Alguns destes também prestaram serviços por designação direta do governo, tais como ser encarregado do seqüestro de propriedades portuguesas no período imediatamente posterior à independência do país, ou, ainda, ser designado Juiz de diligências para dar cabo à sublevação ocorrida em Pernambuco, em 1817, entre outros serviços.

Há, enfim, marcante indistinção entre funções judiciais e funções administrativas (em sentido amplo), especialmente em relação àquelas encarregadas do uso da coerção (junto à polícia e às forças armadas), e do próprio mando político (presidentes de província, por exemplo), além daquelas deliberativas (cargos legislativos), tanto na base quanto no topo da hierarquia judicial. É visível, portanto, a estreita conexão entre o exercício da função judiciária e aquele relativo ao exercício do controle social, com relativo destaque para este último, em especial, se comparado com o desempenho dessas mesmas funções pelos integrantes do poder Judiciário nos dias de hoje, mais diminuto. Esta indistinção entre as funções judiciais e as de controle social, como se sabe, é traço comum à realidade brasileira desde o período colonial (SCHWARTZ, 1979), com forte continuidade durante o período imperial (KOERNER, 1998). Como frisa Martin Shapiro (1981, p. 20-22), em grande medida, o que explica essa aproximação entre as funções judiciais, administrativas e coercitivas relaciona-se às tarefas de conquista de territórios e, no caso brasileiro, de assegurar a integridade territorial do país, como já foi sobejamente demonstrado pela literatura sobre o tema (CARVALHO, 1980). Neste caso, entretanto, mais do que simplesmente impor uma ordem exterior aos potentados locais, a função judicial era a de solidificar alianças e produzir confiança, por parte das lideranças e da população locais, no governo nacional, viabilizando a progressiva consolidação de um Estado nacional efetivo (VELLASCO, 2004). Como se sabe, a função judiciária é fundamental à racionalização das atividades do Estado nacional, 
pois assegura a primazia dos comandos legais nacionais frente aos interesses locais e regionais, permitindo e legitimando, por meio da aplicação de procedimentos previsíveis e indiferenciados, o exercício do governo direto pelos grupos centrais (TILLY, 1996). Como se observa nos dados apresentados, a experiência vivida pela elite judicial do período encontrava-se em perfeita consonância com este conjunto de atividades.

Dessa maneira, pode-se propor um adendo à influente obra de José Murilo de Carvalho, A construção da ordem (1980), sobre a composição social da elite política do Império e seus reflexos sobre a consolidação do Estado nacional brasileiro. Argumenta o autor que o fato da elite política brasileira ser formada, inicialmente, em sua maioria, por magistrados, e não por advogados, como nos EUA, deveu-se ao fato de que aqueles teriam mais interesse em proteger os interesses do Estado, e não interesses de particulares, como se daria no caso destes. De posse dos dados expostos, o que se observa é que esse juízo está, de fato, correto, mas que isso se deve também ao tipo de função atribuída aos magistrados brasileiros do período, em especial, aos ditos letrados, principal fonte de recrutamento para o STJi. A função da magistratura era pouco a de intérprete da lei, mas antes a de uma aliada na manutenção da ordem e da estabilidade, bem como da primazia do poder central ante o conjunto de interesses locais e regionais. Todavia, não se trata, como já foi mencionado, de encarar tais magistrados como agentes de um governo central que mecanicamente reprimem interesses locais, como parecem sugerir as obras clássicas de Raymundo Faoro (2001) e Simon Schwartzman (1982). Antes de ver tal relação como um simples jogo de soma zero, entre grupos locais e centrais, no qual os últimos beneficiar-se-iam da atuação necessariamente fiel e repressiva daqueles magistrados, trata-se de perceber que as funções exercidas por estes inseriam-se em um contexto de mediação e negociação da ordem, contribuindo de modo gradual para a prevalência dos últimos. Somente desta maneira pode-se compreender, por exemplo, que tantos futuros ministros do Supremo Tribunal de Justiça do Império tenham se feito eleger - por grupos locais, vale lembrar - para ocupar cargos junto às diferentes casas legislativas do período, como a Assembléia Geral do Império, as diferentes assembléias provinciais e mesmo as câmaras de vereadores.

Na realidade, o fato dos magistrados ocuparem cargos como os de Juiz de fora, de Desembargador e de Ministro de Estado (diretamente vinculados aos interesses nacionais), bem como aqueles de legisladores nas arenas local, regional e nacional (vinculados aos grupos locais e regionais), sugere a importância da confiança de ambos os grupos para a ascensão na carreira. Percebe-se, todavia, que a predominância dos interesses nacionais foi crescente, com um acréscimo, ao longo do tempo, de carreiras que incluíam cargos de natureza policial, especialmente após a Regência, quando se consolida a autoridade do Estado nacional. A ampla circulação entre as diversas arenas decisórias era, portanto, um requisito praticamente imprescindível para sedimentar a confiança das elites políticas dos diferentes níveis naqueles que posteriormente seriam indicados a integrar a elite judicial do país. Por outro lado, essa necessidade de ocupar muitos postos certamente dificultou a institucionalização da mais alta Corte de Justiça do país, praticamente impossibilitando-a de distinguir-se de outras instituições políticas, ao menos no período ora analisado.

A fim de apreender com maior acuidade a aludida dificuldade de distinção da carreira judicial dos ministros do STJi em relação àquelas políticas, coercitivas e administrativas, procedeu-se nova sistematização dos dados, como se encontra no Quadro 2, em que se busca identificar os perfis de carreira dos magistrados daquela Corte.

QUADRO 2 - PADRÕES DE CARREIRA DOS MINISTROS DO STJI

\begin{tabular}{|c|c|c|c|}
\hline \multirow[t]{2}{*}{ PADRÃO } & \multicolumn{2}{|c|}{ PERÍODO } & \multirow[t]{2}{*}{ TOTAL } \\
\hline & $\begin{array}{l}\text { I REINADOE } \\
\text { REGÊNCIA }\end{array}$ & $\begin{array}{l}\text { II REINÁDO E I } \\
\text { REPÚBLICA }\end{array}$ & \\
\hline Exclusivamente jurídica & $12,5 \%$ (3 de 24$)$ & $14 \%$ (14 de 100$)$ & $\begin{array}{c}13,7 \%(17 \mathrm{de} \\
124)\end{array}$ \\
\hline $\begin{array}{l}\text { Jurídica e defesa jurídica do } \\
\text { estado }\end{array}$ & $0 \%$ (0 de 24) & $1 \%$ (1 de 100$)$ & $0,8 \%$ (1 de 124) \\
\hline
\end{tabular}




\begin{tabular}{|c|c|c|c|}
\hline Jurídica e política & $29,2 \%$ ( 7 de 24$)$ & $27 \%$ (27 de 100$)$ & $\begin{array}{c}27,4 \% \text { (34 de } \\
124)\end{array}$ \\
\hline Jurídica e coercitiva & $12,5 \%$ (3 de 24$)$ & $14 \%$ (14 de 100$)$ & $\begin{array}{c}13,7 \% \text { (17 de } \\
124)\end{array}$ \\
\hline Jurídica e administrativa & $8,3 \%$ (2 de 24$)$ & $2 \%(2$ de 100$)$ & $3,2 \%$ (4 de 124$)$ \\
\hline Jurídica, política e coercitiva & $8,3 \%$ (2 de 24$)$ & $22 \%$ (22 de 100$)$ & $\begin{array}{c}19,4 \%(24 \text { de } \\
124)\end{array}$ \\
\hline $\begin{array}{l}\text { Jurídica, política, coercitiva e } \\
\text { administrativa }\end{array}$ & $16,7 \%$ (4 de 24$)$ & $2 \%$ (2 de 100$)$ & $4,8 \%$ (6 de 124) \\
\hline $\begin{array}{l}\text { Jurídica, política e defesa } \\
\text { jurídica do estado }\end{array}$ & $8,3 \%$ (2 de 24$)$ & $3 \%$ (3 de 100$)$ & $4 \%$ (5 de 124$)$ \\
\hline $\begin{array}{l}\text { Jurídica, política e } \\
\text { administrativa }\end{array}$ & $4,2 \%$ (1 de 24$)$ & $2 \%$ (2 de 100$)$ & $2,4 \%$ (3 de 124) \\
\hline $\begin{array}{l}\text { Jurídica, coercitiva e defesa } \\
\text { jurídica do estado }\end{array}$ & $0 \%$ (0 de 24) & $4 \%$ (4 de 100$)$ & $3,2 \%$ (4 de 124) \\
\hline $\begin{array}{l}\text { Jurídica, coercitiva e } \\
\text { administratwa }\end{array}$ & $0 \%$ (0 de 24) & $1 \%$ (1 de 100$)$ & $0,8 \%$ (1 de 124) \\
\hline $\begin{array}{l}\text { Jurídica, política, coercitiva e } \\
\text { administrativa }\end{array}$ & $0 \%$ (0 de 24) & $8 \%$ (8 de 100$)$ & $6,5 \%$ (8 de 124) \\
\hline $\begin{array}{l}\text { Número médio de cargos } \\
\text { ocupados antes do ingresso na } \\
\text { Corte }\end{array}$ & 8,0 & 6,4 & 6,7 \\
\hline
\end{tabular}

FONTE: os autores, a partir de Brasil. Supremo Tribunal Federal (2007), até 20.set.2007.

NOTA: Preferiu-se excluir o cargo de Provedor da Fazenda dos Defuntos e Ausentes, Resíduos e Capelas, a fim de melhor apreender os dados, já que esse cargo era comumente conferido aos julgadores, sendo uma praxe o acúmulo dele com funções judiciais, quando das primeiras nomeações junto ao poder Judiciário.

Em sentido semelhante àquele apresentado acima, outro dado interessante é o referente aos títulos de nobreza concedidos aos ministros ${ }^{9}: 72,5 \%$ dos futuros magistrados do STJi receberam pelo menos um, com destaque para 14 ministros (11,3\% do total) que receberam mais de três títulos. Entre estes, inclusive, incluem-se algumas das figuras políticas de maior importância e destaque na política do período, tais como Lucas Antonio Monteiro de Barros, Visconde de Congonhas do Campo, Senador e primeiro Presidente da província de São Paulo, cuja descendência, ao exemplo do pai, trilhou as funções judiciais; Candido José de Araújo Vianna, Marquês de Sapucaí, Presidente da província de Alagoas, Deputado (cinco vezes) e Senador por Minas Gerais, Ministro de Estado (duas vezes) e Conselheiro de Estado extraordinário; Antonio Paulino Limpo de Abreu, Visconde de Abaeté, Presidente da província de Minas Gerais, Ministro de Estado (seis vezes), Deputado (cinco

\footnotetext{
9 O já referido título do Conselho foi excluído na construção destes dados, dada a sua obrigatoriedade para o ingresso no tribunal.
}

vezes), Senador; Manoel Ignácio Cavalcanti de Lacerda, Barão de Pirapama, Senador e Presidente do Senado por sete anos; além de várias outras personalidades políticas do período.

No que se refere aos padrões de socialização educacional dos ministros do STJi, corrobora-se a tese do predomínio da formação coimbrã. No total, 69 ministros $(55,6 \%)$ obtiveram seu diploma junto à Universidade de Coimbra, predomínio que se manteve especialmente até a década de 1870 , quando começaram a tomar assento no tribunal os egressos das faculdades de Direito brasileiras, de Pernambuco e de São Paulo, logo deixando de ingressar na Corte os ex-alunos da universidade portuguesa. A nomeação do $72^{\circ}$ integrante da Corte, Ministro João Lopes da Silva Coito, em 1872, pode ser apontada como marco para esta mudança. Desse momento em diante, não mais foram indicados ao tribunal indivíduos com formação superior em Portugal. Até ele, contudo, dos 71 ministros nomeados, 69 haviam passado por Coimbra, perfazendo $97,2 \%$ do total. Mesmo após a inflexão em prol da formação nas faculdades brasileiras, entretanto, interessante padrão pode ser observado: dos 53 ministros no- 
meados nos últimos 21 anos de existência do tribunal (1870-1891), 62,3\% (33 ministros) possuíam formação em Pernambuco, contra apenas 37,7\% (20 ministros) de egressos de São Paulo. Esse predomínio talvez seja explicado em razão do perfil mais liberal da faculdade de Direito paulista, se comparado àquele da instituição pernambucana (ADORNO, 1988), o que provavelmente era visto com ressalvas por parte de quem promovia a nomeação dos cargos.

Outro ponto interessante são os padrões de mobilidade geográfica apresentados nas carreiras dos integrantes do STJi. Há clara predominância de indivíduos, mais uma vez, com ampla circulação entre as diversas províncias do país, indicando vinculação forte destes com a autoridade nacional central. Atentando-se apenas para os deslocamentos decorrentes das nomeações para car- gos públicos (jurídicos, políticos etc.), observase que a maior parte dos ministros veio a exercêlos, em média, em três ou quatro províncias, e são pouquíssimos os casos de indivíduos que realizaram carreira em apenas uma província - estes não passam de $10 \%$ do total. Como reforço deste padrão de grande mobilidade geográfica, percebe-se ainda que a grande maioria dos ministros - em torno de $84 \%$ - deixava seu local de nascimento para ingressar no ensino superior. A forte presença de juízes de fora e de direito, como apontado anteriormente, reforça este ponto. Isto porque estes, a fim de não criarem vínculos locais fortes, eram removidos de comarca a cada três anos, passando, portanto, por muitos cargos e províncias até chegarem ao STJi. Estas informações, relativas à circulação geográfica dos integrantes do STJi, encontram-se sintetizadas no Quadro 3:

\begin{tabular}{|c|c|c|c|}
\hline \multirow[t]{2}{*}{ PADRÃO } & \multicolumn{2}{|c|}{ PERÍODO } & \multirow[t]{2}{*}{ TOTAL } \\
\hline & I REINADO E REGÊNCIA & II REINADO E I REPÚBLICA & \\
\hline $\begin{array}{l}\text { Mobilidade entre local de } \\
\text { nascimento e local do } \\
\text { diploma universitário }\end{array}$ & $78,3 \%$ (18 de 23 ) & $85,4 \%$ (82 de 96$)$ & $84 \%$ (100 de 119) \\
\hline $\begin{array}{l}\text { Mobilidade entre local do } \\
\text { diploma universitário e } \\
\text { local do primeiro cargo }\end{array}$ & $55,6 \%$ (10 de 18$)$ & $90,1 \%$ (90 de 99$)$ & $\begin{array}{c}85,5 \% \text { (100 de } \\
117)\end{array}$ \\
\hline $\begin{array}{l}\text { Mobilidade entre local do } \\
\text { nascimento e local do } \\
\text { primeiro cargo }\end{array}$ & $72,2 \%$ (13 de 18$)$ & $56,7 \%$ (55 de 97$)$ & $\begin{array}{c}59,1 \%(68 \text { de } \\
115)\end{array}$ \\
\hline $\begin{array}{l}\text { Mobilidade entre primeiro e } \\
\text { último cargo }\end{array}$ & $83,3 \%$ (15 de 18$)$ & $66,7 \%$ (66 de 99$)$ & $\begin{array}{c}69,2 \% \text { (81 de } \\
117)\end{array}$ \\
\hline $\begin{array}{l}\text { Ocuparam cargos em mais } \\
\text { de uma província }\end{array}$ & $83,3 \%$ (20 de 24 ) & $95 \%$ (95 de 100$)$ & $\begin{array}{c}92,7 \%(115 \text { de } \\
124)\end{array}$ \\
\hline $\begin{array}{l}\text { Número médio de } \\
\text { províncias }\end{array}$ & 2,8 & 3,7 & 3,5 \\
\hline
\end{tabular}

FONTE: os autores, a partir de Brasil. Supremo Tribunal Federal (2007), até 20.set.2007.

NOTA: Na elaboração do "número médio de províncias", foram computados apenas os cargos profissionais ocupados (jurídicos, políticos, coercitivos e administrativos), excluindo-se da contagem os dados referentes ao local de nascimento e ao do local de obtenção do diploma universitário.

Ainda com relação à distribuição geográfica, cumpre mencionar que há concentração nas regiões de origem (nascimento) dos ministros do STJi. Os nascidos nas províncias da Bahia (39 ministros, 31,5\%) e do Rio de Janeiro (23 ministros, 18,6\%), bem como aqueles nascidos em Portugal (13 ministros, 10,5\%), são majoritários, muito embora não se trate de padrão inteiramente predominante. Tendência semelhante, ainda que mais acentuada, observa-se com relação ao último cargo antes da nomeação para o STJi, já que há claro predomínio daqueles que ocupavam postos nas províncias do Rio de Janeiro (62 ministros, 50\%), da Bahia (28 ministros, 22,6\%) e de Pernambuco (17 ministros, 13,7\%), imediatamente antes da nomeação para a cúpula do poder Judiciário do período. Estas três províncias juntas perfazem mais de $85 \%$ dos casos. Ressalte-se, ainda, que 
estas províncias, conjuntamente com a do Maranhão, foram as primeiras a possuírem Relações. Aquelas da Bahia e do Rio de Janeiro são anteriores ao século XIX, ao passo que a pernambucana e a maranhense instalaram-se nos anos imediatamente prévios à proclamação da Independência. Como as Relações constituíam o destino mais natural para os juízes da época, não é de estranhar-se que os futuros integrantes do STJi fossem nomeados desembargadores nestas províncias. Somente a partir das reformas na década de 1870 é que foram criadas novas Relações, permitindo a diversificação das localidades de onde eram extraídos os ministros.

Por outro lado, situação inversa é observada quando são focalizadas as províncias de início de carreira dos ministros. Neste caso, há certa aleatoriedade, com concentração máxima nas províncias do Rio de Janeiro, Bahia e Minas Gerais, não passando, respectivamente, de 22 (17,8\%), 18 $(14,5 \%)$ e $11(8,9 \%)$ os ministros que iniciaram carreira nestas regiões. Com relativa importância ainda se encontram aqueles que iniciaram carreira junto às províncias de São Paulo (nove ministros, 7,3\%) e Pernambuco (oito ministros, 6,5\%), além daqueles que tiveram sua carreira iniciada em Portugal (oito ministros, 6,5\%). Os 49 ministros restantes (39,5\% do total) tiveram suas respectivas carreiras iniciadas em 14 diferentes províncias e possessões portuguesas (Angola etc.). Em que pesem alguns casos mais pronunciados (Rio de Janeiro e Bahia, especialmente), não é possível falar-se em concentração territorial no início da carreira desses indivíduos. Parece exatamente o contrário, isto é, que se tratava de fazê-los percorrer grande número de províncias ao longo da carreira, especialmente no início, de modo a não criarem vínculos muito fortes com os grupos locais e, aos poucos, ir fazendo regressarem a alguns centros mais importantes, em especial àqueles tradicionalmente favoráveis aos interesses do Estado.

Por fim, deve-se mencionar que há poucos dados que permitam a identificação de mobilidade intergeracional. O perfil de apenas 27 ministros (21,8\% dos casos) apresenta informação relativa à profissão do pai, dos quais 14 são filhos de militares de patentes intermediárias ou elevadas (capitães, majores, coronéis e tenentes-coronéis); nove, de magistrados (dois dos quais são filhos de ministros do próprio STJi); dois, de senado- res; um, de Presidente de província e um outro, de médico. Ainda que os dados não sejam exaustivos, neles predominam as situações de recrutamento interiores à elite, especialmente aquela propriamente estatal, novamente corroborando as tendências observadas anteriormente de identificação entre as funções judiciais e aquelas relativas ao exercício do controle social por parte do Estado.

\section{OS MINISTROS DO SUPREMO TRIBUNAL FEDERAL E AS REPÚBLICAS DO BRASIL (1891-2007)}

O número de ministros que compõe o Supremo Tribunal Federal tem apresentado variações, desde sua instituição, em 1891. Inicialmente formado por 15 ministros, conforme estabelecido na Constituição Federal de 1891, teve seu número reduzido para 11 pelo Decreto n. 19 656, firmado pelo Governo Provisório, em 1931. Este número foi mantido nas Constituições de 1934, 1937 e 1946, sendo novamente alterado pelo Ato Institucional n. 2/1965, que ampliou para 16 o número de ministros da Corte. Em 1969, o Ato Institucional n. 6 alterou mais uma vez a composição do Supremo Tribunal, reduzindo para 11 vagas, magnitude mantida pela Constituição de 1988.

Entre 1891 e 2006, o Supremo Tribunal Federal foi integrado por 156 ministros, indicados pelo Presidente da República e, em sua maioria, aprovados pelo Senado Federal. Entretanto, 21 ministros, nomeados por Getúlio Vargas, durante o governo provisório (1930/1934) e, mais tarde, após 1937, não foram submetidos à aprovação pelo Senado. Getúlio Vargas foi, inclusive pelo tempo que passou à frente da Chefia de Estado, o Presidente que nomeou maior número de ministros do Supremo, chegando a 21 em seus 19 anos de governo. Deodoro da Fonseca (15) e Floriano Peixoto (15) apresentaram, igualmente, alta possibilidade de influenciar a composição da Corte. Se os 15 ministros indicados por Deodoro da Fonseca podem ser compreendidos como condição associada à instituição da nova Corte republicana, a alta cota atingida por Floriano Peixoto em apenas três anos, revela a combinação de ativismo e instabilidade política do período. Também ocorreram, no governo de Floriano Peixoto, as únicas cinco rejeições, pelo Senado Federal, de nomes indicados pelo Presidente da República: Barata Ribeiro, Innocêncio Queiroz, Ewerton Quadros, 
Antonio Sève Navarro e Demosthenes da Silveira Lobo.

Para os objetivos deste trabalho, mais do que considerar os aspectos relativos às variações na magnitude da Corte, ou nas prerrogativas constitucionais de indicação, interessa considerar as características dos indivíduos que são escolhidos e passam a compor o Supremo Tribunal. A fim de melhor considerar as variações temporais, o intervalo de 115 anos abrangido pela existência do tribunal foi seccionado em períodos correspondentes às diferentes configurações institucionais apresentadas pelo sistema político brasileiro: I República (1891-1930), governo Vargas (19301945), II República (1946-1963), autoritarismo militar (1964-1984) e redemocratização (19852006).

\begin{tabular}{|c|c|c|c|c|c|}
\hline \multirow[t]{2}{*}{ CARACTERISTICA } & \multicolumn{5}{|c|}{ PERÍODO } \\
\hline & \begin{tabular}{|c|} 
IREPUBLICA \\
$(1891-1930)$
\end{tabular} & $\begin{array}{l}\text { GOVERNO } \\
\text { VARG AS } \\
\text { (1930-1945) }\end{array}$ & $\begin{array}{c}\text { IIREPUBLICA } \\
\text { (1946-1963) }\end{array}$ & $\begin{array}{l}\text { DITADURA } \\
\text { MIILITAR } \\
\text { (1964-1984) }\end{array}$ & $\begin{array}{l}\text { REDEMO- } \\
\text { CRATIZAÇÃ̈O } \\
\text { (1985-2006) }\end{array}$ \\
\hline $\begin{array}{l}\text { Idade média de ingresso } \\
\text { na Corte }\end{array}$ & 55,6 & 55,3 & 54,6 & 57,9 & 55,4 \\
\hline $\begin{array}{l}\text { Idade média do primeiro } \\
\text { cargo }\end{array}$ & 23,6 & 22,5 & 22,9 & 24,9 & 25,2 \\
\hline Tempo médio de Corte & 8,7 & 10,4 & 11,0 & 8,8 & $8,9^{*}$ \\
\hline $\begin{array}{l}\text { Mobilidade entre local de } \\
\text { nascimento e local de } \\
\text { diploma universitário }\end{array}$ & $71,2 \%$ & $47,6 \%$ & $28,6 \%$ & $33,3 \%$ & $26,7 \%$ \\
\hline $\begin{array}{l}\text { Carreira em mais de um } \\
\text { estado }\end{array}$ & $64,4 \%$ & $19,0 \%$ & $14,3 \%$ & $24,2 \%$ & $26,7 \%$ \\
\hline $\begin{array}{l}\text { Número médio de } \\
\text { estados }\end{array}$ & 2,5 & 1,2 & 1,1 & 1,4 & 1,3 \\
\hline $\begin{array}{l}\text { Número médio de cargos } \\
\text { ocupados }\end{array}$ & 5,6 & 4,8 & 5,3 & 5,5 & 5,3 \\
\hline Anosicargos & 5,6 & 4,4 & 3,4 & 5,8 & 2,1 \\
\hline $\begin{array}{l}\text { Anos de experiência } \\
\text { jurídica prévia }\end{array}$ & 27,4 & 20,5 & 20,1 & 20,9 & 13,6 \\
\hline
\end{tabular}

FONTE: os autores, a partir de Brasil. Supremo Tribunal Federal (2007), até 20.set.2007.

NOTA: * tempo médio de permanência relativo a ministros que já se afastaram do STF; ministros ativos em $2007=$ sem informações.

Examinando as biografias dos ministros do Supremo Tribunal Federal, percebe-se um padrão etário semelhante em todos os períodos analisados: sua trajetória profissional tem início entre 22 e 25 anos, com o primeiro cargo profissional, atingindo o ápice, com o ingresso na Corte, ao redor dos 55 anos. Exceção fica por conta do período do autoritarismo militar, quando a idade média dos ministros subiu para pouco mais de 57 anos. Desvios deste padrão podem ser representados pelos casos dos ministros Epitácio Pessoa, que ingressou no STF, em 1902, com apenas 37 anos e, em situação oposta, Carlos Augusto Oliveira Figueiredo, nomeado em 1911, quando registrava 74 anos de idade. Não foi possível estabelecer uma relação estatisticamente significativa entre idade de indicação e tempo de permanência na Corte, cujas médias variam entre 8,7 anos (I República) e 11 anos (II República). Para a maioria dos ministros (75,6\%), o Supremo Tribunal Federal representa o ápice de sua carreira pública, não ocupando nenhuma outra atividade após o afastamento da Corte. Entre as exceções nessa tendência está o caso do Ministro Epitácio Pessoa, aposentado do Supremo em 1912, eleito Senador nesse mesmo ano e Presidente da República em 1919 (BRASIL. SUPREMO TRIBUNAL FEDERAL, 2007d).

Considerando o estado de nascimento dos 156 ministros do STF, Rio de Janeiro (19,9\%) e Minas Gerais $(19,2 \%)$ destacam-se por uma pro- 
porção superior à sua representação demográfica. É interessante chamar a atenção para o fato de o Rio de Janeiro apresentar uma freqüência expressiva na I República e no governo Vargas. A partir de 1945, observa-se uma ascensão de ministros originários de Minas Gerais, preponderando até a redemocratização posterior a 1985.

Foi possível identificar a profissão do pai em apenas 52 casos (33,3\% dos ministros). Militares de patentes intermediárias, como Coronel, Tenente ou Major, constituem a maior freqüência (23 casos); seguidos por profissionais liberais, como engenheiros, advogados, médicos ou professores (seis), senadores (cinco), deputados (dois), juízes (quatro), desembargadores (três), militares de alta patente, como Almirante e General (três), nobres (dois), membros do STJi ou do STF (dois), ministros e embaixadores (dois). Para pouco mais da metade dos casos com informação disponível, a carreira de magistrado representou mobilidade social em relação ao status profissional ocupado pelos respectivos pais. Um caso exemplar de mobilidade social intergeracional pode ser ilustrado pela biografia de Edmundo Pereira Lins. Órfão de pai e mãe aos quatorze anos de idade, aprendeu o ofício de ourives e ferreiro, sendo, posteriormente, caixeiro no comércio. Desenvolveu seus estudos em um seminário católico, o qual abandonou, posteriormente, para ingressar na faculdade de Direito de São Paulo (1885), enquanto ministrava aulas de Latim e Matemática. Foi nomeado, pelo governo provisório, em 1889, Promotor Público e, posteriormente, Juiz (BRASIL. SUPREMO TRIBUNAL FEDERAL, 2007a).

Estágio crítico na projeção de carreiras públicas é representado pelas condições e oportunidades oferecidas à obtenção de diploma universitário (BOURDIEU, 1989; CARVALHO, 1980). Trata-se de identificar se trajetórias bem sucedidas neste caso, que alcançam a cúpula da carreira no poder Judiciário - estão relacionadas à passagem por instituições escolares específicas, responsáveis por conferir diplomas de maior prestígio e valor no mercado profissional. Exemplo deste fenômeno pode ser encontrado na conhecida interpretação de José Murilo de Carvalho sobre a importância da faculdade de Direito da Universidade de Coimbra para a constituição da elite política nacional, em particular na primeira metade do século XIX, como inclusive já se frisou na primeira parte deste trabalho.
Isolando as instituições universitárias responsáveis pela titulação dos ministros do Supremo Tribunal Federal, pode-se identificar mudanças longitudinais significativas, relativas às oportunidades escolares, sobretudo na área do Direito. $\mathrm{Na}$ I República, 69 dos 73 ministros (94,5\%) colaram grau nas faculdades de Direito de São Paulo e Recife/Olinda, indicando o predomínio destas escolas na formação dos Magistrados nacionais, e, sobretudo, daqueles com ascensão profissional elevada. As faculdades de Direito de Pernambuco e de São Paulo reduziram sua participação ao longo do governo Vargas (11 dos 21 ministros do período), acompanhando um crescimento no grupo de membros formados no Rio de Janeiro (sete). Na II República, nenhum ministro nomeado para o STF foi egresso de Pernambuco, sete formaram-se no Rio de Janeiro, apenas três em São Paulo, mesmo número de oriundos da faculdade de Direito de Minas Gerais. Durante o autoritarismo militar, novamente a Universidade Federal do Rio de Janeiro representou a origem de uma proporção significativa dos ministros (33,3\%), com São Paulo (15,1\%) e, agora, a Universidade Federal do Rio Grande do Sul (15,1\%) aparecendo em seguida. Finalmente, no período democrático posterior a 1985, verifica-se uma elevada dispersão na origem escolar dos ministros, formados em universidades de Rio de Janeiro, Minas Gerais e Rio Grande do Sul (nove casos), mas também de São Paulo, Distrito Federal, Maranhão e Sergipe. Em resumo, a tendência mais nítida, quando se observa a formação universitária dos ministros, é a clara dispersão, com uma mudança de uma situação em que praticamente todos os membros da Corte Suprema eram diplomados em Pernambuco e em São Paulo, para um crescimento, num segundo momento, de egressos da Universidade Federal do Rio de Janeiro e, finalmente, grande diversificação, após o autoritarismo militar. A expansão na rede de ensino superior, com a multiplicação de escolas de Direito no início do século XX certamente representou fator importante para a maior diversificação na origem dos diplomas universitários dos ministros do Supremo Tribunal Federal.

Essa mudança pode ser constatada, igualmente, quando se considera a mobilidade territorial, produto da discrepância entre estado de nascimento e estado de titulação universitária. Na I República, 71,2\% dos ministros do STF obtiveram seu 
diploma universitário fora de seu respectivo estado natal. Este fenômeno apresenta sucessiva redução, chegando a apenas $26,7 \%$ dos ministros, após 1985. A expansão da estrutura universitária pode ter contribuído para este resultado, mas não se deve subestimar, também, a perda de importância de diplomas emitidos por instituições específicas (como foram Recife/Olinda e São Paulo, na República Velha, ou o Rio de Janeiro, mais tarde), como filtros de carreiras ascendentes.

O primeiro cargo profissional ocupado constitui a porta de entrada para a carreira pública, indicando oportunidades desiguais para as trajetórias individuais. Para o conjunto do período, os cargos de Promotor Público (31,4\%) e Juiz (21,8\%), representam o acesso mais freqüente à carreira no Judiciário. Contudo, é possível observar discrepâncias salientes, quando se desagrega essa informação por períodos. Iniciar a carreira diretamente como Juiz ou Promotor constituiu um padrão predominante, durante a I República (78,1\% dos ministros indicados para o STF, entre 1891 e 1930, iniciaram sua vida profissional nesses postos). É provável que o procedimento de indicação de juízes, naquele contexto, tenha contribuído para a freqüência de ingresso na carreira diretamente para aquele posto. Como exemplo, pode-se considerar a biografia de Eloy José da Rocha, nomeado pelo Presidente da província, Borges de Medeiros, e pelo Presidente do Superior Tribunal de Justiça do Estado e, então, Diretor da faculdade de Direito, Manoel André da Rocha, Juiz distrital em São Francisco de Paula. O peculiar neste caso consiste em que a nomeação ocorreu antes mesmo da obtenção do título universitário, quando Eloy Rocha ainda cursava o último ano da faculdade de Direito (BRASIL. SUPREMO TRIBUNAL FEDERAL, 2007c).

Contudo, o início de carreira dos futuros ministros apresentou-se mais modesto em outros períodos: após 1985, por exemplo, apenas 26,6 $\%$ dos indicados para a Corte debutaram como juízes e promotores, enquanto $40 \%$ o fizeram como advogados e $26 \%$, funcionários públicos. Esta informação parece indicar, de um lado, maior seletividade para o acesso a cargos como Juiz e Promotor, logo no início da carreira profissional, e, paralelamente, um aumento na possibilidade de um indivíduo alcançar a cúpula do Judiciário mesmo iniciando carreira fora da magistratura.

QUADRO 5 - PROFISSÕES DE INÍCIO DE CARREIRA DOS MINISTROS DO STF

\begin{tabular}{|c|c|c|c|c|c|c|}
\hline \multirow[t]{2}{*}{ PROFISSÃO } & \multicolumn{5}{|c|}{ PERÍODO } & \multirow[t]{2}{*}{ TOTAL } \\
\hline & $\begin{array}{l}\text { I REPÚ- } \\
\text { BLICA } \\
\text { (1891-1930) }\end{array}$ & \begin{tabular}{|l|} 
GOVERNO \\
VARG AS \\
(1930-1945)
\end{tabular} & $\begin{array}{c}\text { II REPÚBLICA } \\
\text { (1946-1963) }\end{array}$ & $\begin{array}{l}\text { DIT ADURA } \\
\text { MIILIT AR } \\
\text { (1964-1984) }\end{array}$ & $\begin{array}{l}\text { REDEMOCRA- } \\
\text { TIZAÇÃO } \\
\text { (1985-2006) }\end{array}$ & \\
\hline Juzi & 32,9 & - & 14,3 & 18,2 & 13,3 & 21,8 \\
\hline Promotor & 45,2 & 14,3 & 35,7 & 18,2 & 13,3 & 31,4 \\
\hline Advogado & 5,5 & 33,3 & 14,3 & 30,3 & 40,0 & 18,6 \\
\hline Funcionário Público & 12,4 & 42,9 & 35,7 & 21,2 & 26,7 & 21,7 \\
\hline Eletwo & 2,7 & - & - & 6,0 & - & 1,9 \\
\hline $\begin{array}{l}\text { Outros cargos no } \\
\text { Judiciário (Pretor, } \\
\text { Procurador) }\end{array}$ & - & 4,8 & - & 6,1 & 6,7 & 2,5 \\
\hline Outros & 1,3 & 4,7 & - & - & - & 2,1 \\
\hline
\end{tabular}

FONTE: os autores, a partir de Brasil. Supremo Tribunal Federal (2007), até 20.set.2007.

Uma mudança no padrão de mobilidade geográfica fica evidente quando reconstitui-se parte da trajetória profissional empreendida após a conclusão dos estudos universitários. Tal reconstituição é feita por meio do registro de cada um dos cargos e postos públicos ocupados até a nomeação para uma vaga no STF. Na I República, quase dois em cada três $(64,4 \%)$ ministros indicados percorreram mais de um estado ao longo de sua carreira profissional. A trajetória do Ministro Eduardo Pindahiba de Mattos é exemplar desse padrão de mobilidade geográfica, característico da I República: formado em Olinda (1851), é nomeado Juiz municipal e de Órfãos, em Itaguaí (RJ), em 1854, Mangaratiba (1855) e, novamente, Itaguaí (1858). Posteriormente, é 
nomeado Juiz de Direito, em Mogi-Mirim (SP), em 1858. Paralelamente à carreira jurídica, é também Chefe de Polícia do Rio Grande do Sul (1859). Novamente nomeado Juiz, em Turiaçu (MA), em 1861, deixa esse cargo para ser Chefe de Polícia, em Minas Gerais (1863); depois, é Vice-Presidente da província do Espírito Santo e, novamente, Chefe de Polícia, agora, em Pernambuco (1864); ocupa o mesmo cargo, ainda, no Espírito Santo (1865) e no Rio de Janeiro (1867); é nomeado Vice-Presidente da província do Rio de Janeiro (1867). Volta a ser Juiz de Direito, em Rezende (RJ, 1868) e, posteriormente, em Barra Mansa (1874). É nomeado Desembargador da Relação do Ceará (1878) e, depois, removido para a Corte, em 1880, para o cargo de Procurador da Coroa e Juiz da Corte de Apelação do Distrito Federal (1890) (BRASIL. SUPREMO TRIBUNAL FEDERAL, 2007b).

Há uma inversão expressiva no padrão apresentado pelos ministros indicados, entre 1930 e 1964, estabilizando-se, posteriormente, em um quarto dos membros com mobilidade geográfica na trajetória pública. Igualmente, ao considerar o número médio de estados em que os ministros ocuparam postos públicos, verifica-se uma redução de 2,5 estados, durante a I República, até um patamar equivalente à metade, correspondente a 1,3 estados, após 1985. Em outras palavras, podese destacar uma mudança no padrão das carreiras jurídicas, com maior fixação no estado de origem e menor circulação territorial. Contudo, não é possível identificar uma alteração correlata no número médio de cargos ocupados, que oscilou de 5,6, durante a I República, para 5,3, sob as instituições poliárquicas do período posterior ao autoritarismo. A permanência temporal em cada cargo parece apresentar discrepância, reduzida de 5,6 anos (I República), para menos da metade (2,1 anos), após 1985. Mais sugestivo ainda, foi o encurtamento no tempo de carreira, equivalente ao tempo entre o primeiro cargo e a indicação para o STF, que oferece uma medida da experiência adquirida na atividade jurídica: ministros indicados durante a I República gastavam, em média, 27,4 anos entre o início e a chegada na cúpula do poder Judiciário. Esse tempo sofreu ligeira redução, fixando-se em torno de 20 anos, entre 1930 e 1984, para finalmente ser encurtado ao valor médio de 13,6 anos de carreira, entre os ministros indicados durante o ciclo democrático posterior a 1985.
Carreiras mais diversificadas, vinculadas ao estado de origem, com menor mobilidade geográfica, mas também mais breves em sua extensão temporal e com menor fixação em cada um dos cargos intermediários ocupados. O que essa informação pode indicar acerca das mudanças nos padrões de recrutamento para a cúpula do Judiciário? Mobilidade territorial costuma ser interpretada como um processo responsável por reconversão de valores e preferências originais, contribuindo para a formação de elites políticas, sociais, culturais, jurídicas etc., dotadas de coesão e uniformidade (CARVALHO, 1980), reforçando a institucionalização das estruturas capazes de impor custos e barreiras de entrada mais seletivos e rigorosos. A mobilidade territorial da elite imperial, como condição para a ascensão individual nos cargos públicos, e padrões de recrutamento e mobilidade em instituições militares são exemplos do efeito provocado pela circulação geográfica, a qual age como um mecanismo de dissolução de vínculos originais e incorporação de parâmetros institucionais. Se isso é correto, como interpretar as tendências de menor mobilidade geográfica verificadas desde os anos 30 e presentes ainda hoje? Para responder a essa questão, provavelmente seja necessário considerar a expansão institucional do poder Judiciário, com a ampliação de tribunais e da relação juízes/habitantes. À medida em que a estrutura institucional do Judiciário tornou-se mais complexa e dotada de maior cobertura e extensão sobre o território nacional, deve ter ocorrido um aumento na demanda por juízes de primeira instância, tribunais de apelação, tribunais especiais etc., permitindo a progressão de carreiras sem a necessidade do distanciamento geográfico exigido quando essa estrutura era mais rarefeita. Em alguma medida, esse crescimento e burocratização do poder Judiciário, no período posterior a 1930, indicam que tais fatores contribuem, também, para a maior autonomia de seu órgão de cúpula. Em sentido semelhante, pode-se sugerir que esse processo de expansão da estrutura judicial acompanha a tendência do período, em que se consolida a autoridade central ante os grupos locais, os quais passam a ser, em grande medida, dependentes daquela (LEAL, 1997).

Conforme já mencionado, para mensurar a institucionalização de um órgão como o Supremo Tribunal Federal, deve-se considerar (1) a sua diferenciação e o estabelecimento de fronteiras 
em relação a outras esferas institucionais; (2) a sua durabilidade e a resiliência; por fim, (3) a sua autonomia política e operacional face aos poderes Executivo e Legislativo (MCGUIRE, 2004). $\mathrm{O}$ uso de dados relativos aos padrões de carreira dos ministros da Corte permite identificar a existência de processos de diferenciação e em que medida o recrutamento dos membros obedece a um padrão de profissionalização e perícia endógenos, no qual prevalecem carreiras estritamente jurídicas, ou, inversamente, se há presença de maior porosidade e fronteiras mal definidas, com deslocamentos freqüentes entre os campos político (Executivo, Legislativo) e jurídico.

Uma primeira informação relevante para reve- lar esses distintos padrões de recrutamento consiste no registro de filiação partidária, efetuado pelos futuros ministros do STF em algum ponto de suas trajetórias públicas e profissionais. Filiação partidária indica, aqui, uma estratégia de investimento no campo político (BOURDIEU, 1989; GAXIE, 1993), ou, ainda, a constituição de conexões partidárias, eventualmente necessárias para impulsionar as carreiras no campo jurídico, o que indica, precisamente, a fluidez de fronteiras e o potencial da reconversão do capital político (votos, relações, compromissos políticos etc.) em mobilidade profissional no poder Judiciário, em detrimento de um capital profissional específico deste (desempenho, perícia, formação jurídica etc.).

QUADRO 6 - EXPERIÊNCIA JURÍDICA, POLÍTICAEADMINISTRATIVA DOS MINISTROS DO STF

\begin{tabular}{|c|c|c|c|c|c|}
\hline \multirow{2}{*}{$\begin{array}{l}\text { ÂMBITO DA } \\
\text { EXPERIÉNCIA }\end{array}$} & \multicolumn{5}{|c|}{ PERÍODO } \\
\hline & \begin{tabular}{|c} 
I REPÚBLICA \\
(1891-1930)
\end{tabular} & $\begin{array}{l}\text { GOVERNO } \\
\text { VARG AS } \\
(1930-1945)\end{array}$ & $\begin{array}{c}\text { II REPÚBLICA } \\
\text { (1946-1963) }\end{array}$ & $\begin{array}{l}\text { DIT ADURA } \\
\text { MILIT AR } \\
\text { (1964-1984) }\end{array}$ & $\begin{array}{l}\text { REDEMO- } \\
\text { CRA TIZAÇÃO } \\
\text { (1985-2006) }\end{array}$ \\
\hline Filiaçẫo partidária & $50,7 \%$ & $23,8 \%$ & $42,9 \%$ & $30,3 \%$ & $33,3 \%$ \\
\hline $\begin{array}{l}\text { Média de anos entre } \\
\text { filiaçấo partidária e } \\
\text { ingresso na Corte }\end{array}$ & 23,3 & 25,8 & 20,7 & 31,8 & 19,2 \\
\hline $\begin{array}{l}\text { Média de anos entre } \\
\text { filiação partidária e } \\
\text { último cargo }\end{array}$ & 17,1 & 23,6 & 18,0 & 14,2 & 17,0 \\
\hline Poder Executivo & $64,4 \%$ & $14,3 \%$ & $42,9 \%$ & $39,4 \%$ & $26,7 \%$ \\
\hline Poder Legislativo & $43,8 \%$ & $23,8 \%$ & $21,4 \%$ & $21,2 \%$ & $26,7 \%$ \\
\hline Burocracia & $13,7 \%$ & $33,3 \%$ & $28,6 \%$ & $9,1 \%$ & $26,7 \%$ \\
\hline Advoc acia & $9,6 \%$ & $42,9 \%$ & $21,4 \%$ & $30,3 \%$ & $46,7 \%$ \\
\hline Doc ência universitária & $1,4 \%$ & $14,3 \%$ & $7,1 \%$ & $30,3 \%$ & $6,7 \%$ \\
\hline $\begin{array}{l}\text { Carreira exclusivamente } \\
\text { jurídica }\end{array}$ & $11,0 \%$ & $14,3 \%$ & $14,3 \%$ & $24,2 \%$ & $33,3 \%$ \\
\hline
\end{tabular}

FONTE: os autores, a partir de Brasil. Supremo Tribunal Federal (2007), até 20.set.2007.

NOTA: o poder Executivo, o poder Legislativo, a burocracia, a advocacia e a docência universitária não constituem atividades mutuamente excludentes e, por isso, a soma dos percentuais pode exceder $100 \%$.

Na I República, a metade dos membros indicados para o Supremo eram filiados a partidos políticos. A partir de 1930, esta proporção sofre redução significativa, revelando a mudança no padrão de indicações promovido por Getúlio Vargas, com a preferência por indivíduos extraídos fora do campo político constituído pelos partidos republicanos. Essa interpretação pode ser reforçada ao observarse o incremento de indivíduos com passagem pela advocacia e, em menor medida, pela burocracia pública, entre os nomeados durante o primeiro ci- clo governamental de Vargas. As indicações de magistrados recrutados junto a partidos políticos voltam a subir, durante a II República, estabilizando-se, posteriormente, no autoritarismo militar e na redemocratização, em uma proporção próxima a um terço dos ministros. A identificação do momento em que a filiação partidária é realizada indica, para todos os períodos, seu registro precoce dentro da carreira profissional, por conta, provavelmente, de um contexto em que as perspectivas de ascensão ainda não estão nítidas. 
Ao lado da filiação partidária, uma informação relevante sobre as fronteiras entre os campos político e jurídico pode ser extraída por meio da identificação da natureza dos cargos ocupados pelos ministros ao longo de suas trajetórias profissionais. Trata-se de isolar a dimensão do grupo de magistrados que percorreram uma carreira exclusivamente constituída no interior do poder Judiciário, em contraste com aqueles cuja atividade apresenta uma circulação entre postos no Executivo, Legislativo e Judiciário. Mais uma vez, a I República confirma um padrão de recrutamento exógeno: quase dois em cada três ministros apresentaram passagem por postos no poder Executivo (federal ou estadual), e pouco menos da metade $(43,8 \%)$ havia sido eleita para cadeiras no Legislativo, antes da indicação para o Supremo Tribunal. Novamente, uma inflexão pronunciada ocorre a partir dos anos 30 , quando se verifica expressivo declínio de ministros com passagem prévia pelo Executivo ou Legislativo, ao lado do aumento, já mencionado, de indicados com atividade profissional de advogado. Embora em níveis mais modestos do que na I República, entre 1946 e 1984, um expressivo número de ministros ainda revela em seu currículo uma passagem pelo campo político.

Um padrão de recrutamento endógeno, como medida da institucionalização da cúpula do Judiciário, pode ser identificado quando isola-se a informação relativa aos membros do STF que percorreram sua carreira profissional exclusivamente em postos do poder Judiciário (Promotor, Juiz, Desembargador), até a indicação para uma vaga no Supremo. Este grupo é bastante residual (11\%), durante toda a I República, conhecendo um reforço durante $\mathrm{o}$ autoritarismo militar, até atingir a proporção de um terço dos ministros indicados após 1985. Parece indicado proceder à leitura dessa informação sob dois ângulos: de um lado, ela revela uma tendência progressiva na direção de um recrutamento endógeno; por outro, mesmo após 115 anos de constituição do STF, apenas um em cada três ministros que chegam à cúpula do Judiciário o fazem baseados em uma carreira exclusivamente jurídica, o que indica os limites ainda existentes para uma diferenciação com o campo político.

\section{CONCLUSÕES GERAIS E IMPLICAÇÕES DO ESTUDO}

Considerando o conjunto do período analisado, que cobre a indicação de ministros para o STJi e STF, pode-se identificar três grandes mudanças nos padrões de carreira dos ocupantes de cadeiras na cúpula do poder Judiciário brasileiro. Em primeiro lugar, destaca-se uma redução na mobilidade territorial, ao observar-se o estado de nascimento, de obtenção do diploma universitário e o desenrolar da carreira profissional, até o ingresso na Corte. Inicialmente, no Império, mas também na I República, as carreiras dos futuros membros da Corte Suprema foram marcadas por alta circulação geográfica entre estados, condição para a obtenção de um título universitário, em decorrência da concentração de instituições de ensino superior em apenas algumas províncias/estados, como também para o ingresso e ascensão na função pública (não apenas judiciária). Uma inflexão significativa neste padrão ocorre apenas na década de 1930, durante o primeiro governo de Vargas.

Provavelmente, a diversificação institucional na oferta de cursos universitários de Direito, ao lado de uma expansão e de um aumento da complexidade da estrutura do poder Judiciário, tenha contribuído para a constituição de carreiras profissionais mais fixadas no estado de origem dos futuros ministros. Se, até 1870, Coimbra era responsável pela formação jurídica da proporção majoritária dos ministros, ao final do Império, Pernambuco assume a condição de centro formador de dois em cada três ministros, mantendo sua condição quase oligopólica durante toda a I República, e dividindo, agora, este status com a faculdade de Direito de São Paulo. Finalmente, a partir dos anos 30, verifica-se uma forte diversificação das faculdades responsáveis pela titulação dos ministros, com incremento na importância adquirida por universidades de Minas Gerais, Rio de Janeiro e, em menor escala, Rio Grande do Sul. Em contraste, durante a II República, apenas três ministros foram formados em São Paulo, e nenhum em Recife.

Por fim, o aspecto mais importante associado às mudanças nos padrões de recrutamento está relacionado com o lento incremento na proporção de ministros nomeados após carreiras profissionais exclusivamente jurídicas. Durante o Império, embora houvesse limitação para nomeações de indivíduos que exerciam exclusivamente funções judiciais, pouco mais de um em cada dez ministros havia percorrido unicamente profissões jurídicas, e cerca de dois terços dos ministros apresentavam experiência política (no Executivo ou no Legislativo) em seu curriculum, além de ser 
possível observar uma expressiva freqüência na sobreposição de carreiras jurídicas e funções policiais de promoção da ordem e exercício da coerção. Mais uma vez, ruptura saliente ocorre no governo de Vargas, quando se verifica uma diminuição dramática de ministros com filiação partidária. Mas a maior inflexão na seleção de ministros com trajetórias profissionais exclusivamente jurídicas ocorre durante o autoritarismo militar, chegando, após a redemocratização, à proporção de um em cada três ministros.

A partir desse ponto, sugere-se a relevância de uma continuidade dos trabalhos a cerca da composição de cortes judiciais em, pelo menos, duas direções: de um lado, parece relevante explorar a relação entre os achados desta pesquisa (menor mobilidade territorial, mais diversificação escolar e moderada tendência à maior profissionalização a partir das carreiras profissio- nais) e os padrões decisórios adotados por essas cortes em diferentes períodos. Trata-se de verificar se a menor probabilidade de vinculação ao poder Executivo federal, presente em carreiras com menor circulação geográfica e maior vinculação a uma perícia constituída no campo jurídico, corresponde, efetivamente, a decisões mais independentes em relação às preferências daquele poder, potencializando um sistema de checks and balances, como prescrito pelos founding fathers. Paralelamente, estudos comparativos sobre supremas cortes (nos EUA e na América Latina) e Tribunais Constitucionais europeus poderão trazer informações relevantes sobre o efeito das regras restritivas de nomeação de ministros, verificando se a existência de indicações reservadas a candidatos com experiência jurídica repercute em padrões de recrutamento endógenos, bem como no desempenho institucional dessas cortes.

André Marenco dos Santos (amarenco@terra.com.br) é Doutor em Ciência Política pela Universidade Federal do Rio Grande do Sul (UFRGS) e Professor Adjunto do Programa de Pós-Graduação em Ciência Política da mesma Universidade.

Luciano Da Ros (luciano_da_ros@yahoo.com.br) é Bacharel em Direito e Mestre em Ciência Política pela Universidade Federal do Rio Grande do Sul (UFRGS).

\section{REFERÊNCIAS BIBLIOGRÁFICAS}

ADORNO, S. 1988. Aprendizes do poder : o bacharelismo liberal na política brasileira. Rio de Janeiro : Paz e Terra.

BONELLI, M. G. 2001. Os Desembargadores do Tribunal de Justiça do Estado de São Paulo e a construção do profissionalismo (1873-1997). Dados, Rio de Janeiro, v. 44, n. 2, p. 249-290, jun.

2002. Profissionalismo e política no mundo do Direito : as relações dos advogados, desembargadores, procuradores de justiça e delegados de polícia com o Estado. São Paulo : Sumaré.

BONELLI, M. G.; OLIVEIRA, F. L. \& MARTINS, R. 2006. Profissões jurídicas, identidades e imagem pública. São Carlos : UFSCAR.

BOURDIEU, P. 1989. La noblesse d'Etat : Grands Écoles et esprit de corps. Paris : Minuit.
CARVALHO, J. M. 1980. A construção da ordem : a elite política imperial. Rio de Janeiro : Campus.

CARVALHO NETO, E. R. 2000. Sua Majestade, o Presidente da República : estudo de caso do controle de constitucionalidade dos atos do Executivo (1995-1998). Recife. Dissertação (Mestrado em Ciência Política). Universidade Federal de Pernambuco.

CASTRO, M. F. \& RIBEIRO, R. P. 2006. Tribunais e políticas públicas : um estudo comparado. Trabalho apresentado no III Congresso da Associação Latino-Americano de Ciência Política, realizado em Campinas (São Paulo), entre 4 e 6 de setembro. Digit.

EPSTEIN, L. \& SEGAL, J. 2005. Advice and Consent : The Politics of Judicial Appointments. Oxford : Oxford University.

FAORO, R. 2001. Os donos do poder : formação do patronato político brasileiro. São Paulo : Globo. 
GAXIE, D. 1993. La démocratie représentative. Paris : Montchrestien.

GUARNIERI, C. \& PEDERZOLI, P. 1996. La puissance de juger : pouvoir Judiciaire et démocratie. Paris : Michalon.

GUARNIERI, C.; MAGALHÃES, P. \& KAMINIS, Y. 2006. Democratic Consolidation, Judicial Reform and the Judicialization of Politics in Southern Europe. In : GUNTHER, R.; DIAMANDOURUS, P. N. \& SOTIROPOULOS, D. (eds.). Democracy and the State in the New Southern Europe. Oxford : Oxford University.

HELMKE, G. 2002. The Logic of Strategic Defection : Court-Executive Relations in Argentina under Dictatorship and Democracy. American Political Science Review, Washington, D. C., v. 96, n. 2, p. 291-303, June.

KOERNER, A. 1998. Judiciário e cidadania na constituição da República brasileira. São Paulo : Hucitec.

LEAL, V. N. 1997. Coronelismo, enxada e voto : o município e o regime representativo no Brasil. Rio de Janeiro : Nova Fronteira.

MARANHÃO, T. P. A. 2003. Quando o Supremo Tribunal Federal discorda do Presidente da República. Brasília. Dissertação (Mestrado em Ciência Política). Universidade de Brasília.

MCGUIRE, K. T. 2004. The Institutionalization of the U.S. Supreme Court. Political Analysis, Oxford, v. 12, n. 2, p. 128-142, June.

OLIVEIRA, F. L. 2006. Justiça, profissionalismo e política : o Supremo Tribunal Federal e o controle de constitucionalidade das leis no Brasil (1988-2003). São Carlos. Tese (Doutorado em Ciências Sociais). Universidade Federal de São Carlos.
POLSBY, N. W. 1968. The Institutionalization of the U.S. House of Representatives. American Political Science Review, Washington, D. C., v. 62, p. 144-168, Mar.

SADEK, M. T. 2006. Magistrados : uma imagem em movimento. Rio de Janeiro : FGV.

SCHWARTZ, S. 1979. Burocracia e sociedade no Brasil colonial : a Suprema Corte da Bahia e seus juízes (1609-1751). São Paulo : Perspectiva.

SCHWARTZMAN, S. 1982. Bases do autoritarismo brasileiro. Rio de Janeiro : Campus.

SEGAL, J. \& SPAETH, H. 1993. The Supreme Court and the Attitudinal Model. Cambridge : Cambridge University.

2002. The Supreme Court and the Attitudinal Model Revisited. Cambridge : Cambridge University.

SHAPIRO, M. 1981. Courts : A Comparative and Political Analysis. Chicago : Chicago University.

TILLY, C. 1996. Coerção, capital e estados europeus. São Paulo : USP.

VANBERG, G. 2001. Legislative-Judicial Relations : A Game-Theoretical Approach to Constitutional Review. American Journal of Political Science, Washington, D. C., v. 45, n. 2, p. 346-361, Apr.

VELLASCO, I. A. 2004. As seduções da ordem : violência, criminalidade e administração da justiça - Minas Gerais, século 19. Bauru : USC.

WERNECK VIANNA, L.; CARVALHO, M. A R.; MELO, M. P. C. \& BURGOS, M. B. 1996. O perfil do magistrado brasileiro. Rio de Janeiro : IUPERJ.

1997. Corpo e alma da magistratura brasileira. Rio de Janeiro : Revan.

\section{OUTRAS FONTES}

BRASIL. SUPREMO TRIBUNAL FEDERAL. 2007a. Edmundo Pereira Lins. Disponível em : http://www.stf.gov.br/portal/ministro/ verMinistro.asp?periodo=stf\&id=178. Acesso em : 20.set.2007. 2007b. Eduardo Pindahiba de Mattos. Disponível em : http://www.stf.gov.br/portal/ ministro/verMinistro.asp?periodo=stf\&id=117. Acesso em : 20.set.2007. 
2007c. Eloy José da Rocha. Disponível em : http://www.stf.gov.br/portal/ministro/ verMinistro.asp?periodo=stf\&id=180. Acesso em : 20.set.2007.

. 2007d. Epitácio da Silva Pessôa. Disponível em : http://www.stf.gov.br/portal/minis-
tro/verMinistro.asp?periodo=stf\&id=182. Acesso em : 20.set.2007.

. 2007e. Ministros. Disponível em : http:// www.stf.gov.br/portal/ministro/ministro.asp. Acesso em : 20.set.2007. 


\title{
ROUTES THAT LEAD TO THE COURTS: CAREERS AND RECRUITMENT PATTERNS FOR BRAZILIAN SUPREME COURT JUSTICES (1829 -2006)
}

\author{
André Luiz Marenco dos Santos and Luciano Da Ros
}

This article analyzes changes and continuities in recruitment patterns for high-level justices in the Brazilian court system between 1829 and 2006. For these purposes, we analyze data on: 1) social origin and 2) juridical, political and penal system careers for members of the Supreme Courts (Supremo Tribunal de Justiça from 1829-1890; Supremo Tribunal Federal, 1891-2006). We take a separate look at the social attributes of the individuals who have been recruited to these courts, identifying the characteristic traits of each generation of justices, emphasizing the importance of specific institutions of higher education for the prospects of a juridical career, states of origin and cases of geographical mobility within the different periods. We also look at the degree of differentiation in the juridical sphere in relation to spheres that are of a specifically political character, a question that is considered fundamental from the perspective of prospects for institutionalization. Our findings offer clues for comprehending the longitudinal changes that take place in career and recruitment standards for Brazilian supreme courts as well as the social, institutional and political requirements that pertain to the trajectories of this segment of the juridical field. Fundamentally, we have observed a gradual increase in individuals belonging to an exclusively juridical universe: people who have followed careers both in the juridical field and other arenas - whether political or linked to repressive State apparatuses - prevail throughout the periods under consideration. Decreased geographic circulation throughout the careers of future ministers, as well as the diversification of the institutions of higher education where their degrees are obtained (both phenomena particularly pronounced after the first Vargas period) further suggest - although rather paradoxically - the increased autonomy of the Court

KEYWORDS: juridical careers; recruitment patterns; Supremo Tribunal Federal; Supremo Tribunal de Justiça.

\section{LES CHEMINS MENANT À LA COUR: CARRIÈRES ET CRITÈRES DE RECRUTEMENT DES MINISTRES DES INSTITUTIONS MAJEURES DU POUVOIR JUDICIAIRE BRÉSILIEN (1829-2006)}

\section{André Marenco dos Santos e Luciano Da Ros}

Cet article analyse les changements et les continuités dans les critères de recrutement des ministres des institutions majeures du pouvoir judiciaire brésilien de 1829 à 2006. A cet effet, sont examinés les données concernant 1) l'origine sociale et 2) les carrières juridiques, politiques et coercitifs des membres du Supérieur Tribunal de Justice (18299-1890) et du Suprême Tribunal Fédéral (18912006). Nous avons mis à part les attributs sociaux des individus recrutés pour ces tribunaux et nous avons non seulement identifiés les caractéristiques propres à chaque génération de ministres, mais encore souligné l'importance des institutions universitaires spécifiques dans la projection de carrières juridiques, les régions d'origine et le phénomène de mobilité géographique dans des périodes diverses. Nous avons également observé le degré de différence de champs juridiques par rapport à ceux de nature typiquement politique, ce qui est considéré comme essentiel à l'institutionalisation de cet organe de justice. Les résultats nous permettent de mieux comprendre le changements longitudinaux qui existent dans les standards de carrière et recrutement pour les cours suprêmes brésiliennes et les exigences sociales, institutionnelles et politiques qui accompagnent les trajectoires dans cette parcelle du champ juridique. Nous observons spécialement une lente croissance du nombre d'individus originaires de l'univers essentiellement juridique, et il ressort que souvent ce sont des individus ayant eu des carrières tant dans le domaine juridique que dans d'autres domaines, soit politiques soit liés à l'appareil coercitif de l'État, qui l'emportent. Le fléchissement de la circulation géographique au long de la carrière des futurs ministres, et la diversification de ses instituitions supérieures décernant des titres, tous deux surtout après la première Ère Vargas, suggèrent, bien que ce soit assez paradoxal, un accroissement de l'autonomie de l'institution.

MOTS-CLÉS: carrières juridiques ; standards de recrutements ; Supérieur Tribunal de Justica ; Suprême Tribunal Fédéral 